\title{
Theology of nature: Reflections on the dogmatic doctrine of creation
}

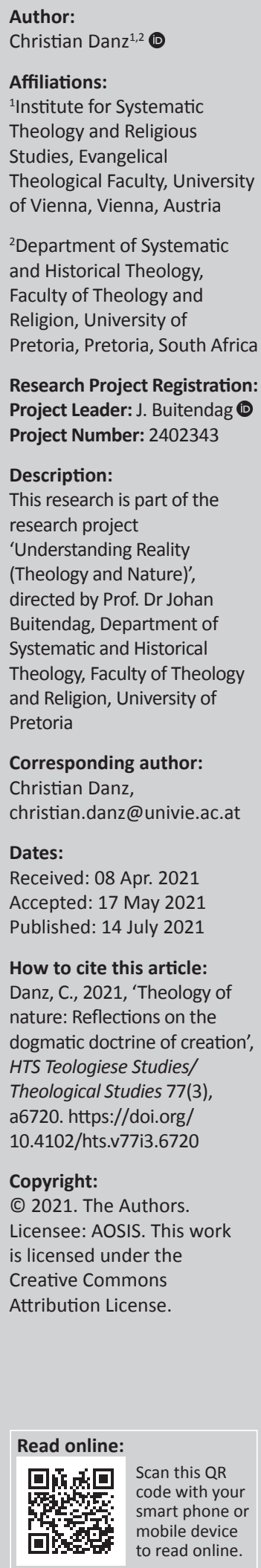

\section{Author:}

Affiliations:

reology and Religious

Theological Faculty, University

of Vienna, Vienna, Austria

of Systematic

Faculty of Theology and

Religion, University of

Research Project Registration:

Project Leader: J. Buitendag $\mathbb{1}$

Description

This research is part of the

research project

(Theology and Nature)',

directed by Prof. Dr Johan

uitendag Department of

Theology, Faculty of Theology

and Religion, University of

Corresponding author:

Dates:

Accepted: 17 May 2021

dogmatic doctrine of creation

10.4102/hts.v77i3.6720

is licensed under the

Creative Commons

Attribution License.

mobile device

to read onlin
The doctrine of creation and the knowledge of nature have come into tension in modernity. Against this background, the article discusses the basic problems of a theology of nature starting from a systematic theology of religious communication. Dogmatic statements about the world as God's creation are not about a description of nature and reality but about a reflexive account of Christian-religious communication. The object of the doctrine of creation is thus the world-related contents of the Christian religion as well as the function these have in it. Thus, both the critique of the representational version of the doctrinal tradition's conception of creation and its reflexive turn in 20th-century Protestant theology are taken up and carried forward in such a way that the belief in creation is not understood as a general qualification of the world but is related to the concrete contents of religious communication.

Contribution: The article proposes a new formulation of the traditional doctrine of creation on the basis of a systematic theology of religious communication. This approach is intended to avoid a coexistence of religious belief in creation and scientific explanation of the world, as well as their being pushed into one another. By transferring the belief in creation to Christianreligious communication, the latter thematises how religious contents are created in the Christian religion.

Keywords: theology and nature; ecotheology; doctrine of creation; theology of religious communication; Jürgen Moltmann.

\section{Introduction}

With the onset of the ecological crisis or climate change, the doctrine of creation has again become the focus of theological attention. Theology has taken up these discussions under headings such as 'deep ecology', 'deep incarnation' and 'ecotheology' (cf. ed. Gregersen 2015; Horrell/Hunt/Southgate 2010; Knight 2007). These discussions have been accompanied by a complete reconstruction of the traditional dogmatic doctrine. If the dogmatic, doctrinal tradition of Lutheranism's annihilatio mundi was still its divinely determined final goal, now the preservation of creation is almost inversely connected with the will of God. Already these mutually exclusive theological versions of the fate of creation raise the question not only of how a theological doctrine of creation is to be elaborated in the 21st century, but also of what its object is in the first place. Do theology and its statements relate to nature, and how does the theological description of the world as creation relate to scientific descriptions of the world? An answer to the question of how nature is to be understood theologically will not avoid including the systematic problems of the doctrine of creation under the conditions of modernity.

Belief in God the Creator has formed a fundamental part of the Christian religion since its beginnings, but the European Enlightenment led to a complete reconstruction of the old dogmatic teachings of the Creator-God who created the world out of nothing in 6 days (cf. Danz 2007). To be sure, the theological doctrinal tradition of antiquity had already linked the doctrine of creation with soteriology and, like Augustine, had already understood the difference between God and the world as the very content of the faith in creation. However, these soteriological determinations of creation were still naturally inserted into a cosmologicalmetaphysical framework. Martin Luther also distinguished the religious idea of God from philosophical conceptions that grasped it as a component of the explanation of the world. Thereby he limited the knowledge of God soteriologically, so that the salvation given in faith is the reason, limit and norm of the thought of God (cf. Danz 2007:70-87; Wittekind 2018:82). Consequently, with him the will of God for salvation moves into the centre of the faith in

Note: Special Collection: Theology and Nature, sub-edited by Johan Buitendag (University of Pretoria). 
creation, which thus extends the faith in salvation to the world. ${ }^{1}$ However, regardless of the soteriological intensification of the faith in creation, the reformer still unquestionably assumes a metaphysical and cosmological framework of the doctrine of God, so that the knowledge of God the Creator is also possible outside of faith. This metaphysically representational version of the doctrine of creation, which was systematic and elaborated in the old Protestant dogmatics (cf. Danz 2007:88-95; Schmidt 1893:110-134), was irretrievably destroyed by the Enlightenment. Both biblical and epistemological criticism, which were established in Protestant theology during the 18th century, dissolved the old, representational version of the dogmatic doctrine of creation and reformulated the belief in creation in the framework of new foundations of theology as a science in consciousness-based concepts of religion. In the process, the cosmological components of the old doctrinal version were dropped, as was the claim to explain in any way the origin of the world or of nature. Instead, the soteriological elements of the doctrinal tradition's belief in creation came into focus. In Friedrich Schleiermacher's recasting of the doctrine of creation in his The Christian Faith, one can study this reconstruction of the doctrinal concept of creation theology. By relating God to the whole world, the Berlin theologian marks the difference between religious and scientific interpretation of the world, because God is precisely a religious interpretation of the whole of reality that applies only to religion (cf. Schleiermacher 1999:193-204 [§§ 39-41]). Schleiermacher's reformulation of the doctrine of creation was largely followed by Protestant theology in the 19th and 20th centuries even where it contradicted him.

As a result, the transformation of the traditional, dogmatic, doctrinal concept of creation since the Enlightenment led to a dissolution of its representational conception as well as its new formulation as a religious interpretation of the world, which it is strictly distinguished from a scientific explanation of the world and nature. Religious statements about the creation of the world by God refer to a level other than natural scientific descriptions. ${ }^{2}$ There is no connection between these two views. Thus, the criticism of the representational version of the doctrine of creation from the doctrinal tradition has been considered and included in the theological description of the world as creation, but with the result that now both doctrinal views of the world stand unconnected next to each other. Since the 1970s, this development of the dogmatic doctrine of creation has been increasingly perceived as problematic. It isolates theology not only from the modern natural sciences but above all from the pressing problems of the present, as they are revealed in the ecological crises of modern industrial societies (cf. Crisp 2020:41-104; Deuser

1.Cf. Martin Luther's interpretation of the first article of the Creed in the Kleiner Katechismus: Luther (1982:510f.).

2.In the Protestant theology of the first half of the 20th century, there is a broad consensus on this question. Cf. Barth (1957:22): 'Natural science has free space beyond what theology has to describe as the work of the Creator. And theology may and must move freely where a natural science [...] has its limit'. Cf. also Bultmann (1967:128-137). Cf. on this Danz (2007:199-208).
1999; Knight 2007; Moltmann 2002a:13-36; Neville 1992; Peacocke 1993). However, how can the dogmatic doctrine of creation and scientific explanations be interlinked? Is it sufficient to push both into each other in a new way? ${ }^{3}$

In what follows, another proposal is made to reformulate the dogmatic doctrine of creation under the conditions of modernity. This takes its starting point from a systematic theology of religious communication (Danz 2019b, 2020). The dogmatic statements about the world as God's creation are not about a description of nature and reality but about a reflexive account of Christian-religious communication. The subject of the doctrine of creation is thus the world-related contents of the Christian religion as well as the function that these contents have in it. Thus, both the critique of the representational version of the doctrinal tradition's conception of creation and its reflexive turn in German-speaking 20th-century Protestant theology are taken up and carried forward in such a way that the belief in creation is not understood as a general qualification of the world but is related to the concrete contents of religious communication. In order to make plausible the proposed reformulation of the dogmatic doctrine of creation, the difficulties with which the designs are first confronted, bringing faith into creation, and scientific theories into context, shall first be traced. This is exemplified by Jürgen Moltmann's doctrine of creation, one of the most important and influential conceptions from the second half of the 20th century, in which faith in creation and the modern knowledge of nature are juxtaposed. The third section then explores the question of how God and nature are to be understood within the framework of a systematic theology of religiouscommunication. On this basis, the concluding section outlines the main features of a reflexive version of the dogmatic doctrine of creation.

\section{Theology of nature, or Jürgen Moltmann's ecological doctrine of creation}

Jürgen Moltmann had already presented a theology of nature in the 1980s (Moltmann 1985). With his ecological doctrine of creation, he reacts to the ecological crises increasingly perceived in Western societies since the 1970s. The systematic basis of his doctrine of creation, which by its very title God in Creation marks its new deployment, is a recasting of the concept of faith, which he had first elaborated in his programmatic Theology of Hope (Moltmann 1966). Continuing the ideological-critical theology of his two Göttingen teachers, that of Hans Joachim Iwand, as well as the realist eschatology of Otto Weber, Moltmann no longer interprets the act of faith as the eschatological correspondence of God and reality, but as the erection of the difference between

3.Thus, Wilfried Härle in his Dogmatik makes the proposal to intertwine the belief in creation and the origin of the world in such a way that the former is related to the inner (non-causal) reason of the origin of the world and the latter to the outer inner (non-causal) reason of the origin of the world and the latter to the outer reason of creation. Cf. Harle (2000:420): Understood in this way, the creation statement neither stands beside nor against the scientific explanation but relates to it by interpreting it in a certain way. If the being created of the scientifically explicable and explainable denotes its inner reason, then the creation statemen always also refers, indeed decisively, to the determination of the created, that is, to that as which it is intended and meant by God, and thus to the goal toward which it is on its way'. 
reality and God's new creation. ${ }^{4}$ Faith is thus understood as an orientation toward the eschaton, the coming of God's new creation. Because the knowledge of the difference between God's new creation and reality is connected with faith, faith is at the same time participation and solidarity with the unredeemed reality.

Structurally, faith understood as Christian hope thus interlocks two sides, opposition to reality and solidarity with it. Christian hope is bound to the revelation of God and thus not only cannot be derived from the world but is also opposed to it. There is a radical discontinuity between the new world of God and the present reality of human beings. The image of Christian hope and its reflexive structure is the resurrected crucified. ${ }^{5}$ In the event of the resurrection of the crucified, which owes itself to a newly creative act or an apocalyptical act of God, the meaning of the world as a whole emerges, which cannot be derived from the world and is realised against it. Already the early Theology of Hope as well as its continuation in the theology of the cross turn against the theological doctrinal tradition and its individualistic narrowing of the understanding of faith (cf. Moltmann 1987:9f.). Theology, if it wants to take a stand on the pressing problems of the present, must become more universal. In his 1985 creation doctrine, Moltmann transferred this programme to faith in creation, not only connecting it with his new formulation of the concept of faith from the Theology of Hope but also correcting it.

Moltmann's theology of nature, which he outlines in his ecological doctrine of creation, builds on his version of the concept of faith. Thus, it does not result from nature itself, but from the revelation of God in Jesus Christ. ${ }^{6}$ Moltmann extends Karl Barth's theology of revelation by transferring it to cosmology. The faith in creation is a component of the faith based on God's self-revelation in Jesus Christ as a present event. A religious experience of the world as God's creation arises only together with faith as an orientation towards the coming of God as well as a solidarity dealing with the reality connected with it (cf. Moltmann 1985:67). The principle of knowledge of the new creation of God is the Holy Spirit. Only in the Spirit is Jesus Christ to be recognised as the historical ground of God's new creation or of God's coming kingdom of glory, which cannot be derived from the world. Moltmann intertwines three dimensions in the theologically constructed religious experience: the orientation towards the coming new creation, which points to Jesus Christ as its historical ground, and in which God's new creative action becomes visible. In the faith in creation protology, 'messiah$\log y^{\prime}$ and eschatology are connected. Thus, it does not only

4.Cf. Moltmann (1968:26): "Correspondence to God is possible only through contradiction; agreement with his word only in the confession of the cross; expectation of the future of his truth only in the experience of history, i.e., in solidarity with the suffering of the waiting creature'.

5.Cf. Moltmann (1966:14): 'The contradiction in which hope places man in relation to the present reality of himself and the world is precisely the contradiction from which this hope itself is born, it is the contradiction of the resurrection to the cross'.

6.Cf. Moltmann (1985:66): 'Every natural theology assumes the self-revelation of nature as God's creation. Every theology of nature, on the other hand, interprets nature in the light of the self-revelation of the creative God. [...] Not what nature contributes to the knowledge of God, but what the concept of God contributes to the knowledge of nature is to be examined'. refer to the beginning of creation, but it describes God's creative work as a process that is structured in itself. ${ }^{7}$

From what has been explained, a Trinitarian construction of the faith in creation results. This Trinitarian construction explicates the structure of the revelation-theological version of the concept of faith in a universal cosmological perspective. As God's creation, nature is recognisable to faith alone. Only in the Spirit are traces of God perceptible in world as creation. Moltmann constructs faith as self-referential, so that exclusively for faith the world is a likeness of God, which as nature points to the coming kingdom of glory. ${ }^{8}$ Theology of nature is thus a function of Trinitarian pneumatology, but not vice versa. Its transfer to cosmology has the task not only of understanding the reality of the world as the stage of the drama of salvation but also of including the world and nature within it. However, the experience of the world as God's creation and as a parable of the coming glory is bound to faith and is not accessible outside of it, nor can it be derived from the world (cf. Moltmann 1985:76f.). For faith and only for it, God is present in creation and in each individual as spirit, which as creative power points to the coming glory of the kingdom of God. ${ }^{9}$

In order to overcome the coexistence of faith in creation and natural science, Moltmann relates his Trinitarian doctrine of creation to the natural scientific descriptions of the cosmos. Although he assumes that both are distinct and refer to different levels (cf. Moltmann 1985:204), in view of the ecological crisis it must be a matter of bringing the doctrine of creation and natural science into a new relationship of convergence. ${ }^{10}$ This is found in the idea of open systems. ${ }^{11}$ The evolutionary process described by modern natural sciences is taken up and related to the triadically structured process of divine creation, namely protology, 'messiah-logy' and eschatology. On this basis, nature and the cosmos appear as open systems that point to the transcendence of God (cf. Moltmann 1985:213, 2002b:45-67). Moltmann transfers this theological interpretation of the universe, which takes up its still-outstanding wholeness, to the process of nature and its theoretical interpretations. In this way, scientific thematisations of nature are to be broken up, as it were, and

7.Cf. Moltmann (1985:68): "Creation" denotes God's initial creation, his historical creation and the completed creation. The idea of God's unity is held only in the concept of a process of creation that is meaningfully coherent in itself. This process gets its meaning from its eschatological goal'.

8.Cf. Moltmann (1985:72): 'The tangible reality of the world contains within itself the traces of creation in the beginning These traces are at the same time a reflection of the coming glory. Every knowledge of the world "as" creation is therefore a metaphorical knowledge of this world as a likeness of the world to come'.

9.Cf. Moltmann (1985:219f.): From the Trinitarian doctrine of creation, which pneumatologically continues the dynamic pantheism, follows: 'The God present in the world and in every part is the creative Spirit. It is not only the Spirit of God present in the evolving world, but rather God the Spirit with his uncreated and creative energies'

10.Cf. Moltmann (2002b:45). 'The draft of an eschatological doctrine of creation with the help of open systems theory and its communication is intended to serve this task, without the fulfillment of which man and nature have no chance of survival'. (Moltmann 2002b:64)

11.With the idea of 'open systems' Moltmann takes up the debate of the 1970s to bring theology and natural science into a new conversation. However, Moltmann's take on this debate remains undercomplex and beholden to his own theological intentions as he uses it to distinguish and contrast open and closed systems. intentions as he uses it to distinguish and contrast open and closed systems.
However, as Moltmann himself partially acknowledges (cf. Moltmann 1985:211), a system can only be open if it is fully self-referential, that is, closed. 
placed in the open horizon of the future. For only theology knows about the still-unfinished whole (cf. Moltmann 2002a:31). This view of the cosmos is in Moltmann's construction not at all accessible to the natural sciences. Only theology knows the real and true structure of the world as a whole, as well as its meaning and purpose through the resurrection of the crucified. By transferring its knowledge to the natural sciences and their interpretation of the world, it also brings them to an actual and true knowledge of reality and its eschatological goal, the new creation of God.

Natural science and theology are reconnected in Moltmann's universal doctrine of creation. This works only by means of the fact that theology with the resurrection of the crucified one claims a knowledge for itself, which is in principle neither accessible to the natural sciences nor to other sciences. Seen from today, the claim of such a theological universal science, as it was elaborated in the second half of the 20th century by Moltmann and others, ${ }^{12}$ is no longer comprehensible. The assertion that only theology has the actual true view of reality because of God's revelation is a mere postulate that passes off its own theological construction as truth and reality.

\section{God and nature in a systematic theology of religious communication}

Moltmann's attempt to reconnect faith in creation and knowledge of nature within a theology of nature can no longer be continued, because the theological view of nature is postulated as the real and true one. Under the conditions of a differentiated scientific cosmos and a plural culture, such a claim, as was still made by the German-speaking theologists of the second half of the 20th century, is no longer convincing. The Christian-religious interpretation of the world as God's creation is one worldview amongst others, but not the one in which the meaning of the world alone is revealed. This pluralisation and differentiation of worldviews in the modern age is to be assumed. The criticism of the traditional objective version of the doctrine of creation is also to be taken up. The belief in creation is neither about the actual insight into the process of the origin of the world, nor is it about an alternative interpretation of the world's reality against the natural sciences. So how then are the creation statements of the Christian religion, and their references to nature and the world, to be understood? Not, as will be suggested in the following, as descriptions of reality and nature. The worldand nature-related statements of the Christian religion are not representational but rather serve as a reflexive function. In them the Christian religion presents itself. Only in this way is the alternative of the juxtaposition of faith in creation and natural science, as well as that of pushing of the two into each other, able to be overcome (cf. Wittekind 2018:115-132).

This excludes the understanding of the theology of nature as a kind of natural theology, as if nature or the natural process

12.Like Moltmann, Wolfhart Pannenberg also elaborated a theological universal theory in the second half of the 20th century, which absorbs the modern natura theory in the second half of the 20th century, which absorbs the modern natural
sciences and claims for theology a knowledge of the true structure of the world, sciences and claims for theology a knowledge of the true str
which is not accessible outside of it. Cf. Boss (2006:135-344). itself already had a religious dignity. Against the background of the modern critique of knowledge, such a conception is not possible, at least not for a scientific theology, because it comes about solely through a back-projection of the faith in creation onto nature. With Moltmann, therefore, one had to start from nature as it occurs in religion, whereby, in contrast to him, the religious statements are not transferred to nature. Likewise Moltmann's trinity-theological version of the doctrine of creation is to be taken up but to be put on a different systematic basis. The Trinitarian doctrine of God does not explicate the process of nature and its actual or deeper understanding but rather the Christian religion as an understanding of self and world integrated in communication and produced communicatively. Only in this way does the function of faith in creation for the Christian religion become clear.

The starting point is the religious idea of God: In the Christian religion, God comes from God through God as God (cf. on this formula Jüngel 1992:521-534). This formula of structuring the idea of revelation is to be transferred to the Christian religion, which presents itself as religion in the Trinitarian idea of God as a self-referential and structured event knowing itself as religion. The aim of the considerations to be presented is that religion is a triadically structured event, which is integrated in communication and arises only in this as religion (cf. Danz 2019b:118-139). For the justification of religion, there is no recourse to preconditions given outside of religious communication, such as a religious subject or a religious object. The preconditions of the Christian religion exist only in and for it, namely as components of the religion. The Christian religion is thus bound to the use of religious communication as religion, out of and in which it constitutes itself as religion. This is exactly what the formula of God comes from God through God as God is supposed to say, the structure of which is now to be explained.

As a religion, Christianity arises in the interrelationship of three elements, that of interdependence, appropriation and representation. This means first and foremost: God comes from God. The Christian religion is dependent on the fact that it already exists in the culture as a differentiated form of communication. Without existing religious communication, which is passed on as religion, the Christian religion cannot arise. Furthermore, God always encounters us through the words of our language, which are handed down in the religious tradition. However, the handed-down Christian religion is not yet religion itself but only a hint of it. The Christian tradition handed down in culture becomes religion only when it is appropriated and presented as religion by individuals. The moment of this understanding and appropriation of Christian-religious communication is the second element of the structure of the Christian religion. It is not contained in the tradition and therefore represents an element of its own, which cannot be derived from it. For the Christian religious tradition can also be understood at any time non-religiously, that is historically, politically, 
aesthetically, naturally and so on. As a religion, the Christian religion arises only when its communication is understood religiously, and this communication expresses and signifies religion and nothing else. The word 'God' always comes from cultural communication, but God becomes the representation of religion only through appropriating the understanding of God. In it God comes from and through God. However, religion must not only be appropriated as understood in order for it to be constituted but must also be symbolically represented and articulated. This is the third element of the structure from whose context the Christian religion emerges, a structural element that is also independent. Without symbolic representation there can be no religion. A merely internal or invisible religion is a mere theoretical construct and an implausible attribution (hence the suggestion of Luckmann 1991). Because it is not visible, it cannot be recognised. Christian-religious communication thus succeeds when its given communication is appropriated in a way that is understanding and symbolically represented by the individual, that is when the word 'God' is used and employed as God in a religious manner or sense.

God comes from God through God as God. With the idea of God, the Christian religion represents in itself that it constitutes itself as religion out of the interrelation of dependence of religious communication, its understanding appropriation [verstehende Aneignung] and representation. Its non-constructible success is here called 'faith'. It is the symbol-productive reality of the Christian religion. This is bound to the understanding use of communication and is thus both a knowing and self-referential communication event. For religion consists precisely in the fact that communicated contents, such as the media-bound transmission of the memory of Jesus Christ, are meant as religion and not as politics, aesthetics or whatever else. Excluded by the outlined concept of Christian religion is the idea of an unconscious or implicit religion. If religion is constituted such that its practitioners know what they are doing when they communicate religiously, then there cannot be an unconscious religion.

With its contents, the Christian religion presents itself as religion. However, religious contents such as God, Jesus Christ and the Holy Spirit are not only an expression of religion, but at the same time a reflection of religion within itself. For with its contents, the Christian religion describes how it itself comes into being and functions as religion. Only with this is the systematic content of the structural formula God comes from God through God as God caught up. The Trinitarian idea of God represents the dependence of the Christian religion on the religious tradition of the memory of Jesus Christ, its understanding appropriation and symbolic representation. Thus, the doctrine of the Trinity is constitutive for the Christian idea of God. It describes the structure of the Christian religion, in which this religion comes into being and is passed on in history. The task of systematic theology is to construct the Christian religion as a self-transparent, selfreferential and in-and-of-itself structured communication event (on the underlying relationship between theology and religion, cf. Danz 2021:139-154).

The result of these present considerations is that God comes in the religious communication from, and through, and as God to the world. What does this mean for the reference of the Christian religion towards nature, and what function does this have for it? In order for the Christian religion to be continued in history, that is, in order for it to be appropriated in religious communication, it must be recognisable. It is not about God at all, but about God as God is connected with the memory of Jesus Christ. The Christian idea of God is shaped by the Bible. By being related to the biblical scriptures, religious communication is recognisable as Christian. However, the Bible is neither independent, nor does it consist of religion outside of its religious use, as the old Lutheran scriptural principle assumes, nor does the Christian religion consist in the content statements of the Bible. It depends on the discernment of these texts as religion (cf. Danz 2019a:113-127). The contents themselves, which are used in religion, do not yet determine whether they are also meant as religion. The latter is tied to the religious use that people make of the Bible. Just as the Bible can be used non-religiously at any time without changing anything in its contents, so non-religious contents can and will always be included in Christian-religious communication. They do not become religious content by virtue of their special content or certain characteristics, but solely by virtue of their religious use and their use in Christian-religious communication. In this and in no other sense is nature an object of Christian religion. If nature or the natural process of the cosmos is included in Christian-religious communication, then they serve to represent and articulate religion. Because religion is selfreferential and in modernity has been differentiated into an autonomous system amongst others, Christian-religious communication is not about world explanation, ethics, saving the world or anything else. What this means for a dogmatic doctrine of creation is now to be sketched in conclusion.

\section{On the dogmatic function of the doctrine of creation in a systematic theology of religious communication}

In the structure of the old Lutheran dogmatics, the doctrine of creation forms a component of the doctrine of God and is itself differentiated once again into the subject areas of creation and providence, whereby the latter is subdivided into the doctrines of conservatio, concursus and gubernatio. ${ }^{13}$ This structuring of the doctrine of creation will be presented in what follows, but not in the representational way in which the faith in creation was discussed in premodern dogmatics, as this can no longer be viably continued in modernity. Rather, the criticism of the metaphysical-cosmological version of the doctrine of creation and its theological doctrinal tradition is to be considered within a new version of the doctrine. For this reason, the dogmatic doctrine of creation is

13.Cf. Schmidt (1893:117): "But the providence of God proves itself more closely in that God I. sustains what has already been created in the world, II. cooperates in everything that goes on in it, and III. directs and guides everything in it'. 
transferred to Christian-religious communication, and the world-related statements of the Christian religion are understood reflexively and not objectively (cf. on the following also Wittekind 2018:125-132). The object of the dogmatic doctrine of creation is the Christian religion itself. In the faith in creation, it represents how the contents of religion come into being and which contents can become the object of Christian-religious communication. Thus, the faith in creation and its statements about the world are not only an expression of religion or a religious qualification of reality as a whole of God's creation. Rather, this has a certain function for the Christian religion, namely to thematise in it how and which contents can become religious contents.

The integration of the doctrine of creation into the doctrine of God, which the doctrinal tradition had already undertaken, and is also taken up in Moltmann's new version, makes clear that the faith in creation is not about reality per se, but only insofar as God is related to it. ${ }^{14}$ The subject and object of creation faith are nature and reality as they occur in the Christian religion but not statements about the world as such. For the dogmatic doctrine of creation, this means that it describes how religious statements arise in the Christian religion. Because God, as explained above, represents the success of religious communication as a self-referential and self-transparent structured event, God designates the basis of religious belief in creation. God comes to the world in religious communication, in which God, who in religion represents and reflects religion, is related to communicated contents, which thereby become religious contents. Furthermore, the Christian faith in creation has to be explained in a Trinitarian way: God always comes from God through God as God. Faith in creation, conservation and providence form a context structured in itself, which represents in the Christian religion its transparent functioning as religion in contents.

The first moment represents the creation belief, the coming of God from God. It extends those contents that can be the subject of religious communication to all possible contents. Everything can be the object and content of the Christian religion. Whether contents become religious contents, meaning that they refer to God, does not depend on any special characteristics of these contents. Nature and reality ex nihilo become the content of the Christian religion. By the Christianreligious communication taking them up, these contents lose their 'cultural' meaning and function exclusively for the representation of the Christian religion. This is always determined by content but does not merge into the communicated content.

The dogmatic doctrine de creatione thematises how religious contents come into being in the Christian religion and which contents can become those of religion. In that everything real can become the object of Christian religious

14.Cf. Moltmann (1985:66f.): 'Not by itself does the world reveal itself as God's creation. Only through his revelation as its creator, sustainer and savior does God make the world manifest as his creation' communication, the dogmatic doctrine de creatione describes the framework of religious communication (cf. Wittekind 2019:129). However, with the genesis of the contents of the Christian religion, as discussed by the doctrine of creation in the narrower sense, its functioning is not yet completely described. For its existence as religion depends on the transparent religious use people make of these contents. This aspect of the Christian religious communication describes the doctrine of the conservation of the world by God. Its existence as religion has religious communication only by means of the fact that with all its contents religion is meant. If the Christian religion takes nature and cosmos into its communication, then it does not use these contents in a cultural sense but distinguishes between the content and religious sense. The religious view of the world hangs on the fact that, as it is likewise from God, it is also through him. Furthermore, the dogmatic doctrine of the conservatio of the world by God has a reflexive function for the Christian religion. This presents with the conservation faith for itself the existence of the religious world interpretation as dependent on religious communication. Without religion, there is no religious image of the world, but this is precisely what is tied to the religious use of communication by human beings. As the conservation of the world by God presupposes its creation, so the inclusion of the world in Christian-religious communication and its existence presupposes that the contents of communication are used as religion.

Whilst the doctrine of creation deals with the genesis of religious contents and the doctrine of conservation with the binding of these contents to religious use, the doctrine of providence relates Christian-religious communication to the individual and his or her concrete life in the world. Only with the doctrine of providence does the individual come into the view of the religious thematisation of faith in creation by applying it to him- or herself (cf. Wittekind 2019:131). For Christian-religious communication succeeds only when people include their own lives in the world within religious communication and understand them religiously. If religion is constituted at the concrete events of life, so that these are taken up in the religious communication and are meant as expression and representation of religion, then God comes from God through God as God to the world. Religion comes into being only when religious communication is applied to it by people in their own lives. Religion depends on the successful use of Christian-religious communication by the individuals. However, whether religious communication succeeds is neither derivable nor constructed, so that with every single event in the life of a human being the possibility remains not to include it in religious communication and to understand it non-religiously.

Creation, conservation and providence describe as a context structured in itself how God comes to the world in the Christian religion. God comes to the world only in religion and specifically, in the success of Christian-religious communication in view of the concrete events that affect 
people in their lives. Only by taking these into religion does God come to the world. Even with this, faith in creation does not relate to nature and the world in such a way that it explains them or contains their actual truth. Rather, it addresses how Christian religion functions transparently and self-referentially as religion in light of concrete events in human life. The world- and nature-related statements of the Christian religion have a function for it as a religion and its religious articulation. On the basis of a systematic theology of religious communication, as proposed here, faith in creation and the modern view of nature can indeed be related to each other without being shoved into each other in an apologetic interest. It is also possible to relate the faith in creation to the individual and concrete in the world and not to stop at a general qualification of the world as God's creation.

\section{Acknowledgements Competing interests}

The author declares that he has no financial or personal relationships that may have inappropriately influenced him in writing this article.

\section{Author's contributions}

C.D. is the sole author of this research article.

\section{Ethical considerations}

This article followed all ethical standards for research without direct contact with human or animal subjects.

\section{Funding information}

This research received no specific grant from any funding agency in the public, commercial or not-for-profit sectors.

\section{Data availability}

Data sharing is not applicable to this article as no new data were created or analysed in this study.

\section{Disclaimer}

The views and opinions expressed in this article are those of the author and do not necessarily reflect the official policy or position of any affiliated agency of the author.

\section{References}

Barth, K., 1957, Die Kirchliche Dogmatik, Vol. III/1, 3rd edn., Zollikon, Zürich.

Boss, G., 2006, Verlust der Natur. Studien zum theologischen Naturverständnis bei Karl Rahner und Wolfhart Pannenberg, Tyrolia, Innsbruck.

Bultmann, R., 1967, Zum Problem der Entmythologisierung, Glauben und Verstehen. Gesammelte Aufsätze, vol. 4, 2nd edn., pp. 128-137, Mohr Siebeck, Tübingen.

Crisp, O.D., 2020, God, creation, and salvation. Studies in reformed theology, T\&T Clark, London.

Danz, C., 2007, Wirken Gottes. Zur Geschichte eines theologischen Grundbegriffs, Neukirchner, Neukirchen-Vluyn.

Danz, C., 2019a, 'Autor und Autorität der Schrift. Anmerkungen zur Schriftlehre der Dogmatik', in U. Heil/A. Klein/A. Schellenberg (eds.), Autor und Autorität.
Historische, systematische und praktische Perspektiven. Wiener Jahrbuch für Historische, systematische und praktische Perspektiven. Wiener Jahr
Theologie, vol. 12, pp. 113-127, Vienna University Press, Göttingen.

Danz, C., 2019b, Gottes Geist. Eine Pneumatologie, Mohr Siebeck, Tübingen.

Danz, C., 2020, Jesus von Nazareth zwischen Judentum und Christentum. Eine christlogische und religionstheologische Skizze, Mohr Siebeck, Tübingen.

Danz, C., 2021, 'Theologie und religion. Überlegungen zu einer umstrittenen Unterscheidung', in U. Heil/A. Schellenberg (eds.), Theologie als Streitkultur. Wiener Jahrbuch für Theologie, vol. 13, pp. 139-154, Vienna University Press, Göttingen.

Deuser, H., 1999, Kleine Einführung in die Systematische Theologie, Reclam, Stuttgart. Gregersen, N.H. (ed.), 2015, Incarnation. On the scope and depth of Christology, Fortress Press, Minneapolis, MN.

Härle, W., 2000, Dogmatik, 2nd edn., De Gruyter, Berlin.

Horrell, D.G.,/Hunt, C.,/Southgate, C., 2010, Greening Paul: Re-reading the Apostle in a time of ecological crisis, Baylor University Press, Waco, TX.

Jüngel, E., 1992, Gott als Geheimnis der Welt. Zur Begründung der Theologie des Gekreuzigten im Streit zwischen Theismus und Atheismus, 6th edn., Mohr Siebeck, Tübingen.

Knight, C.C., 2007, The God of nature: Incarnation and contemporary science, Fortress Press, Minneapolis, MN.

Luckmann, T., 1991, Die unsichtbare Religion, Suhrkamp, Frankfurt am Main.

Luther, M., 1982, 'Der kleine Katechismus', in Bekenntnisschriften der evangelischlutherischen Kirche, pp. 501-542, 9th edn., Vandenhoeck \& Ruprecht, Göttingen.

Moltmann, J., 1966, Theologie der Hoffnung. Untersuchungen zur Begründung und $z u$ den Konsequenzen einer christlichen Eschatologie, 6th edn., Kaiser, München.

Moltmann, J. (ed.), 1968, 'Gottesoffenbarung und Wahrheitsfrage', in Perspektiven der Theologie. Gesammelte Aufsätze, pp. 13-35, Kaiser, München.

Moltmann, J., 1985, Gott in der Schöpfung. Ökologische Schöpfungslehre, Kaiser, München.

Moltmann, J., 1987, Der gekreuzigte Gott. Das Kreuz Christi als Grund und Kritik christlicher Theologie, 9th edn., Kaiser, München.

Moltmann, J. (ed.), 2002a, 'Theologie in der Welt der modernen Wissenschaften', in Wissenschaft und Weisheit. Zum Gespräch zwischen Naturwissenschaft und Theologie, pp. 13-36, Kaiser, Gütersloh.

Moltmann, J. (ed.), 2002b, 'Schöpfung als offenes system', in Wissenschaft und Weisheit. Zum Gespräch zwischen Naturwissenschaft und Theologie, pp. 45-67, Kaiser, Gütersloh.

Neville, R.C., 1992, God the creator: On the transcendence and presence of God, State University of New York Press, Albany, NY.

Peacocke, A., 1993, Theology of a scientific age. Being and becoming-Natural, divine, and human, Fortress Press, Minneapolis, MN.

Schleiermacher, F., 1999, Der christliche Glaube nach den Grundsätzen der Evangelischen Kirche im Zusammenhange dargestellt (1830/31), M. Redeker (ed.), De Gruyter, Berlin.

Schmidt, H., 1893, Die Dogmatik der evangelisch-lutherischen Kirche, dargestellt und aus den Quellen belegt, 7th edn., Bertelsmann, Gütersloh.

Wittekind, F., 2018, Theologie religiöser Rede. Ein systematischer Grundriss, Mohr Siebeck, Tübingen 